\title{
TIMBER TRADE PRACTICE
}




\title{
TIMBER TRADE PRACTICE
}

\author{
Jack H. Leigh, F.I.W.Sc., \\ Technical Consultant to the Price \& Pierce Group, \\ Examiner for the Institute of Wood Science in Timber \\ Economics and Administration, \\ Timber Trade Federation Arbitrator
}

Alan G. Randall
Former Manager of Price \& Pierce Group Technical Services,
Timber Trade Federation Arbitrator and Authorised Stress Grader

Fourth Edition

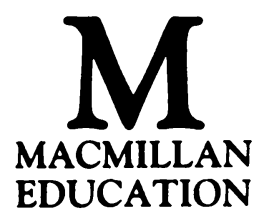


(c) Jack H. Leigh and Alan G. Randall 1965, 1981

Softcover reprint of the hardcover 4th edition 1981 978-0-333-23885-1

All rights reserved. No reproduction, copy or transmission of this publication may be made without written permission.

No paragraph of this publication may be reproduced, copied or transmitted save with written permission or in accordance with the provisions of the Copyright Act 1956 (as amended).

Any person who does any unauthorised act in relation to this publication may be liable to criminal prosecution and civil claims for damages.

First edition 1950

Second edition 1953

Third edition 1965

Reprinted 1973, 1974

Fourth edition 1981

Reprinted 1986

Published by

MACMILLAN EDUCATION LTD

Houndmills, Basingstoke, Hampshire RG21 2XS

and London

Companies and representatives

throughout the world

ISBN 978-1-349-03848-0 ISBN 978-1-349-03846-6 (eBook)

DOI 10.1007/978-1-349-03846-6 


\section{Contents}

Preface to the Fourth Edition $x$

Acknowledgements $\quad x i$

List of Tables xiii

List of Figures xiv

1. A Short History of the Timber Trade 1

2. Geographical Background 7

2.1 General 7

2.2 USSR 9

2.3 Finland 9

$\begin{array}{lll}2.4 & \text { Sweden } & 10\end{array}$

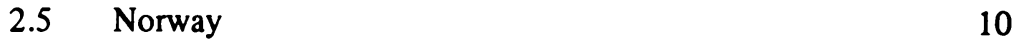

2.6 Lower Baltic States 11

2.7 Other European Countries 11

$\begin{array}{lll}2.8 \text { Canada } & 12\end{array}$

$\begin{array}{lll}2.9 & \text { USA } & 14\end{array}$

2.10 Central and South America 15

2.11 The African Continent 16

2.12 Australasia $\quad 18$

2.13 South-east Asia and the Pacific 19

2.14 Japan 20

$\begin{array}{lll}2.15 & \text { Statistics } & 22\end{array}$

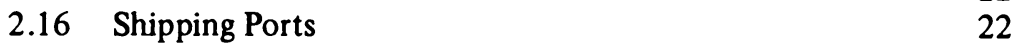

$\begin{array}{ll}2.17 & \text { Importing Ports }\end{array}$

3. The Imported Timber Trade 42

$3.1 \quad$ Structure of the Trade $\quad 42$

3.2 Grading and Shippers' Marks 46

3.3 Methods of Importing Timber 53

3.4 Supply and Demand 55

4. The Softwood Trade 59

$\begin{array}{lll}4.1 & \text { General } & 59\end{array}$ 
4.2 Consumption $\quad 62$

4.3 Purchases 63

$\begin{array}{lll}4.4 & \text { Arrivals } & 64\end{array}$

$\begin{array}{lll}4.5 & \text { Stock } & 64\end{array}$

$\begin{array}{lll}4.6 & \text { Prices } & 64\end{array}$

5. Shipping 66

5.1 Elementary Definitions 66

5.2 The Charter Party 70

5.3 Nubaltwood Charter Party, $1973 \quad 74$

5.4 The Bill of Lading $\quad 87$

5.5 Liner Bill of Lading 90

5.6 Liner Through Bill of Lading 93

5.7 The Hague Rules 94

5.8 The Caspiana Case 95

6. Marine Insurance 96

6.1 General 96

$\begin{array}{lll}6.2 & \text { The Policy } & 97\end{array}$

6.3 The Policy Form 99

$\begin{array}{ll}6.4 & \text { The Perils Insured Against } \\ 6.500\end{array}$

$\begin{array}{ll}\text { 6.5 Losses Covered by Marine Insurance } & 101\end{array}$

6.6 The Timber Trade Federation Insurance Clauses 103

6.7 War and Strike Risk Clauses $\quad 111$

6.8 Strikes Expenses Insurance 114

6.9 Assignment Certificate, Claims, Subrogation 114

6.10 Wood Goods, Insurance Definition and Plywood Insurance 116

7. Timber Contracts I 117

7.1 Basic Legal Aspects of Sale of Goods 117

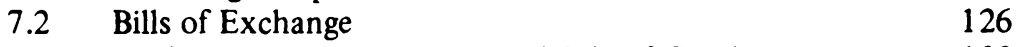

7.3 Uniform Laws on International Sale of Goods 128

8. Timber Contracts II 130

$\begin{array}{lll}8.1 \text { General } & 130\end{array}$

8.2 Albion $1980 \quad 133$

$\begin{array}{lll}8.3 & \text { Uniform } 1980 & 157\end{array}$

9. Timber Contracts III 175

$\begin{array}{lll}9.1 & \text { Russia } 1952 & 175\end{array}$

$\begin{array}{lll}9.2 & \text { Trancif } 1971 & 182\end{array}$

9.3 Ligcon $1961 \quad 185$

$\begin{array}{lll}9.4 & \text { Eucon } 1964 & 190\end{array}$

$\begin{array}{lll}9.5 & \text { Pacif } 1958 & 195\end{array}$

9.6 Ecancif $1958 \quad 200$

$\begin{array}{lll}9.7 & \text { Fobra } 1957 & 205\end{array}$

$\begin{array}{lll}9.8 & \text { Poland-Albion } 1933 & 210\end{array}$ 
9.9 Unicif $1952 \quad 212$

9.10 American Hardwood Lumber 1960

9.11 C.I.F. Reselling Contracts 221

9.12 Ex-ship Reselling Contracts 226

9.13 Scanref $1964 \quad 228$

$\begin{array}{lll}9.14 & \text { Scanrex } 1964 & 230\end{array}$

10. Timber Contracts IV 232

10.1 Plycif $1957 \quad 232$

10.2 Plydef $1972 \quad 246$

$\begin{array}{lll}10.3 & \text { Parcif } 1963 & 250\end{array}$

10.4 Pardel $1973 \quad 253$

$\begin{array}{lll}10.5 & \text { Britfibre } 1978 & 257\end{array}$

11. Arbitration 266

11.1 General 266

11.2 The Reference Note 267

11.3 The Rules of Arbitration 268

$\begin{array}{lll}11.4 & \text { The Award } & 275\end{array}$

$\begin{array}{lll}11.5 & \text { Scottish Arbitrations } & 277\end{array}$

12. Importing Wood Goods - Customs and Docks Procedure -

Claims

12.1 Importing Wood Goods 278

12.2 Import Entry Procedure 283

12.3 Examination of Shipment - Claims, etc. 289

12.4 Examination of Documents 290

12.5 Examination of Goods and Ships 291

$\begin{array}{lll}12.6 \text { Claims } & 295\end{array}$

13. Transport, Handling, Storage and Office Routine 303

$\begin{array}{lll}13.1 \text { Transport } & 303\end{array}$

$\begin{array}{ll}13.2 \text { Handling } & 305\end{array}$

$\begin{array}{lll}13.3 & \text { Storage } & 306\end{array}$

$\begin{array}{lll}13.4 & \text { Office Routine } & 307\end{array}$

14. Inland Sales, Charges and Costs $\quad 310$

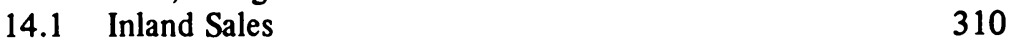

14.2 Conversion and Machining Charges and Costs 313

15. Measurement, Calculations and Units of Sale 316

$\begin{array}{lll}15.1 & \text { Historical } & 316\end{array}$

$\begin{array}{ll}15.2 \text { Units of Measure } & 317\end{array}$

$\begin{array}{ll}15.3 \text { Methods of Calculating } & 319\end{array}$

$\begin{array}{lll}15.4 & \text { Standard Sizes } & 321\end{array}$

15.5 General Observations $\quad 325$ 
$\begin{array}{ll}15.6 & \text { Units of Sale } \\ 15.7 & 326\end{array}$

$\begin{array}{lll}15.7 & \text { Imperial Measure } & 333\end{array}$

$\begin{array}{lll}15.8 \text { Hardwoods } & 334\end{array}$

16. Grading Rules of Timber 339

$\begin{array}{lll}16.1 \text { General } & 339\end{array}$

$\begin{array}{ll}16.2 \text { Finland } & 340\end{array}$

$\begin{array}{lll}16.3 & \text { Sweden } & 350\end{array}$

$\begin{array}{lll}16.4 \text { Poland } & 350\end{array}$

$\begin{array}{lll}16.5 \text { Russia } & 350\end{array}$

16.6 Canada - West and East Coasts 350

$\begin{array}{lll}16.7 & \text { USA Softwoods } & 366\end{array}$

$\begin{array}{lll}16.8 \text { Brazil } & 367\end{array}$

$\begin{array}{ll}16.9 \text { Czechoslovakia } & 367\end{array}$

$\begin{array}{ll}16.10 \text { Austria } & 367\end{array}$

$\begin{array}{ll}16.11 \text { South Africa } & 367\end{array}$

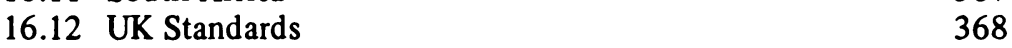

16.13 Moisture Content of Softwood 368

$\begin{array}{ll}16.14 \text { Hardwoods } & 369\end{array}$

$\begin{array}{lll}16.15 \text { Plywood } & 374\end{array}$

16.16 Possible Changes in Grading Systems 378

$\begin{array}{lr}\text { 17. Softwood Surfaces } & 379\end{array}$

$\begin{array}{ll}17.1 \text { Sawing } & 379\end{array}$

$\begin{array}{lll}17.2 & \text { Planing } & 383\end{array}$

18. The Home Grown Timber Trade 385

$\begin{array}{lll}18.1 \text { General } & 385\end{array}$

18.2 The Forestry Commission 386

18.3 The Structure of the Home Grown Trade 387

18.4 The Future of Home Grown Timber 389

19. Specialised Branches of the Trade 392

19.1 Plywood and Veneer Trade $\quad 392$

19.2 The Door Trade 395

19.3 The Fibre Building Board Trade 396

19.4 The Particle Board Trade 398

20. Trade Associations and Authorities 401

20.1 The Timber Trade Federation of the United Kingdom 401

20.2 The Home Timber Merchants Association of England and Wales

20.3 The Timber Research and Development Association 404

20.4 The Princes Risborough Laboratory 408

20.5 The Institute of Wood Science 409

20.6 The British Wood Preservation Association 409 
20.7 The Fibre Building Board Federation 410

20.8 The Fibre Building Board Development Organisation Ltd 410

20.9 The Chipboard Promotion Association 411

21. Developments in the Timber Trade 412

21.1 Timber Preservation $\quad 412$

21.2 Stress Grading of Timber $\quad 417$

21.3 Packaged Timber $\quad 420$

21.4 Finger Jointing $\quad 422$

21.5 Laminated Timber $\quad 425$

21.6 Timber Connectors $\quad 425$

21.7 Trussed Rafters $\quad 426$

Glossary of Timber Trade Terms $\quad 429$

$\begin{array}{lr}\text { Index } & 459\end{array}$ 


\section{Preface to the Fourth Edition}

The authors wish to express their appreciation for the help and co-operation which has been extended to them by the Price and Pierce Group, without whose readily available facilities this book could not have been written. In particular, we thank our Chairman, Mr H. C. Gilbert, for his encouragement by ensuring that the comprehensive experience of the Group's wide knowledge could be utilised.

The third edition of Timber Trade Practice was published in 1965 and it is possibly true to say that in the intervening period of some 15 years more changes have taken place in the timber trade than in the previous 100 years. There are now at least 30 TTF Contract Forms and, in addition, charter parties have been revised, and we have seen the introduction of metrication, decimal currency, stress grading, unitisation in the form of packaging and truckbundling, changes in the method of marketing, new forms of documentation by way of computerised specifications and changes in shipping procedure.

All these developments are subject to constant negotiation and revision. This book can only review them as they exist at the time of writing and point out the principles that should be understood by the reader. Changes between writing and publication - often quite extensive - are likely but cannot be anticipated.

Jointly, we have served the trade for a total of about 92 years, and during that time we have been involved in practically every, if not every, aspect of trade procedure. In latter years we have been principally employed in the agency business - so becoming very familiar with the problems which arise between both the shippers and the buyers. These are considerable, and while it is often merely a question of language misunderstanding, they are sometimes due to changing methods of marketing and interpretation of contract terms which do not always satisfy the changes in trade structure or the quite extraordinary marketing conditions which have developed in recent years.

We trust that readers will appreciate the difficulty of producing this book, in which we have tried to anticipate possible future changes and at the same time have endeavoured to avoid expressing personal opinions by merely stating the facts as we understand them at the present time. We should like to quote from the Preface to the third edition: 'there is no substitute for reading contracts, charters and documents carefully before signing and ensuring that they agree with each other as well as being correct in themselves'.

J. H. LEIGH

A. G. RANDALL 


\section{Acknowledgements}

It would not have been possible to prepare this book without the generous and whole-hearted co-operation of many people and authorities, both outside and inside the trade. To all these the authors tender their sincere appreciation for the valuable assistance which they have received. In particular, they wish to thank the following for their permission to reproduce the material mentioned:

Benn Publications Ltd (extracts from Shipping Marks on Timber); Chamber of Shipping of the United Kingdom (extracts from and copies of Nubaltwood and other charters); Institute of London Underwriters Association (extracts from and copies of insurance clauses); Timber Trade Federation of the United Kingdom (extracts from and copies of contract forms and statistics); Finnish Sawmill Owners Association and the Association of Finnish Sawmillmen (Softwood Grading Rules).

The authors' thanks are due to the following, who supplied much detail, information and statistics in the preparation of the text:

Chapter 2 - Geographical Background. Colleagues in the various companies of the Price and Pierce Group.

Chapter 3 - The Imported Timber Trade - Mr P. T. Dransfield, Brewster and Co. (Woking) Ltd; Mr Tim Spencer, Tim Spencer and Co. Ltd, Westgate-onSea.

Chapter 4 - The Softwood Trade. Timber Trades Journal articles.

Chapter 5 - Shipping. Mr Eric Hawkes, Leafe and Hawkes (Chartering) Ltd, Hull.

Chapter 6 - Marine Insurance. Mr A. P. Mayne and Mr E. R. Lawson, Sedgwick Forbes Marine Ltd, London.

Chapter 7 - Timber Contracts. Legal Aspects Mr G. A. Clifton, William Crump and Son, London: Timber Trade Federation of the United Kingdom.

Chapter 11 - Arbitration. Mr H. Gordon Craig, Chairman of the Timber Arbitrators Association.

Chapter 13 - Transport, Handling, Storage and Office Routine. Mr W. J. Hall, Freight Marketing Services, British Rail.

Chapter 15 - Measurements, Calculations and Units of Sale. Mr Victor Serry, Chairman of the BSI Metrication Committee.

Chapter 16 - Grading Rules. Mr Jack A. Baird, The Swedish Finnish Timber Council, Retford. Mr Paavo Miettanen, Finnish Sawmill Owners Association. 
Chapter 18 - Home Grown Trade. Mr J. R. Aaron, Forestry Commission. Chapter 19 - Specialised Branches of the Trade (Stress Grading): Mr H. Gordon Craig.

Chapter 20 - Trade Associations and Authorities. Mr H. J. Bocking, $\mathrm{Mr}$ A. J. Garratt and Mr C. K. Norman, Timber Trade Federation of the United Kingdom; The Timber Research and Development Association; The Princes Risborough Laboratory; The British Wood Preserving Association; The Institute of Wood Science.

To all others who have assisted in many ways, our grateful thanks. 


\section{List of Tables}

1.1 Imports from 1788 to 1833

1.2 Softwood Sources of Supply - percentage of U.K. Import

Page

$2.1 \quad$ U.K. Softwood Imports - Countries of Consignment

2.2 U.K. Hardwood Imports - Areas of Consignment

2.3 U.K. Hardwood Imports - Value

2.4 U.K. Hardwood Log Imports - Areas of Consignment 25

2.5 U.K. Hardwood Log Imports - Value 25

2.6 U.K. Plywood Imports - Countries of Consignment 26

2.7 U.K. Plywood Imports - Value 26

2.8 U.K. Particle Board Imports - Countries of Consignment 27

2.9 U.K. Particle Board Imports - Value 28

2.10 U.K. Fibre Building Board Imports - Countries of Consignment 28

2.11 U.K. Fibre Building Board Imports - Value 29

2.12 Major U.K. Ports of Entry and Port Authorities 38

2.13 Percentage of Total Import by Ports 39

4.1 Wholesale Price Index of Building Materials - Basis 1970

9.1 Reselling Contracts 222

12.1 Import Duties on Timber and Wood Products 281/2

12.2 P.L.A. Table of Charges 288

15.1 Basic Timber Sizes - BS 4471

15.2 Basic Timber Lengths - BS 4471

15.3 Reduction from Basic Sizes 323

15.4 Canadian Processed Sizes converted to Metric 324

15.5 Conversion from Imperial to Metric - Sizes and Value 329

15.6 Running Metres in Cubic Metre 330

15.7 Board Feet in Cubic Metre 331

15.8 Precise Conversion Factors 332

16.1 Finnish Grading Rules - Defects 346/7

16.2 Finnish Grading Rules - Knots 349

16.3 Russian Marks 351

16.4 Cutting Requirements for N.H.L.A. Grades 373

18.1 Forestry Commission - Land and Plantations 386

21.1 Efficiency Rating of Finger Joint Profiles 424 


\section{List of Figures}

1.1 Wholesale Price Index of Wood Products - Basis 1970

2.1 U.K. Softwood Imports - Volume and Value 20

2.2 U.K. Hardwood Imports - Volume and Value 21

2.3 U.K. Plywood Imports - Volume and Value 21

2.4 U.K. Particle Board Imports - Volume and Value 22

2.5 Map of White Sea Ports 30

2.6 Map of Finnish Ports 31

2.7 Map of South Swedish Ports 32

2.8 Map of Swedish Ports - Upper, Middle and Lower 33

2.9 Map of Lower Baltic Ports 34

2.10 Map of U.S.S.R. Ports 35

2.11 Map of East Canadian Ports 36

2.12 Map of West African Ports 37

3.1 Reproduction of Shipping Marks on Softwood 47

3.2 Reproduction of Shipping Marks on Hardwood 48

5.1 Nubaltwood Bill of Lading 75

7.1 Specimen Bill of Exchange 127

12.1 Reproduction of General Import Entry Form - C.10 284

16.1 Finnish Grading - Size and number of knots on edge 344

16.2 Finnish Grading - Size and number of knots on better face 345

16.3 Finnish Grading - Deformities 348

18.1 Forestry Commission Conservancy Boundaries 388

18.2 Forestry Commission Production 390

21.1 Stress Grading - Projected Pattern of Knots 419

21.2 Finger Joint Profiles 423

21.3 Trussed Rafter Design 427 